\title{
Hinweise Fur Autoren - Instructions To Authors
}

Infusionstherapie 1992;19:341-342

Ethische und rechtlíche Voraussetzungen: Zur Publikation eingereichte Manu-skripte müssen bei Untersuchungen an Probanden oder Patienten die Erklärung enthalten, daß das

Versuchsprotokoll von einer Ethikkommission genehmigt wur-de und somit den ethischen Standards der Deklaration von Helsinki 1964 ent-spricht. Gleichzeitig ist die Einwilligung der Versuchsperson nach Aufklärung im Text des Manuskriptes zu fixieren. Hínweise, die auf die Identität der Versuchsperson schließen lassen, sind zu vermeiden.

Tierversuchsvorhaben bedürfen gleichfalls der Genehmigung und müssen den Forderungen des deutschen Tierschutzgesetzes in seiner Fassung von 1986 ent-sprechen. Auf diese Genehmigung ist im Manuskript hinzuweisen. Arbeiten, die nicht aus der Bundesrepublik Deutschland stammen, müssen einen vergleich-baren Hinweis tragen.

1. Allgemeines, Verlagsrecht

Bitte senden Sie Ihr Manuskript direkt an die Schriftleitung: Prof. Dr. Helmuth Forst, Klinikum

Großhadern, Institut für Anästhesiologie, Marchioninistraße 15, W-8000 München 70, Fax (089)

7409054. Beiträge erscheinen als Übersichtsarbeiten, Originalarbeiten, laufende klini-sche

Studien, Kurzmitteilungen, Kasuistiken, klinisch-pathologische Konferen-zen, Kongreßberichte, Informationen für die Klinik und Briefe an die Heraus-geber.

Originalarbeiten, laufende klinische Studien und Kurzmitteilungen sollten in englischer Sprache

abgefaßt werden. Alle anderen Beiträge können wahlweise in deutscher oder englischer Sprache eingereicht werden. Das Manuskript soil in satzreifem Zustand in vierfacher Ausfertigung eingereicht werden. Die Entscheidung über die Annahme erfolgt aufgrund mehrerer Gutachten. Eine Kopie des Manuskripts soil grundsätzlich beim Autor verblei-ben. Typographische Gestaltung und redaktionelle Bearbeitung sind dem Ver-lag vorbehalten.

Für iedes Manuskript muß in einem Begleitschreiben von alien Autoren durch Unterschrift bestätigt werden, daß die eingereichte Arbeit oder Teile hiervon (Ausnahme:

Kongreßmitteüungen) bislang weder veröffentlicht wurde(n) noch gegenwärtig zur anderweitigen Veröffentlichung eingereicht ist/sind, sowie daß alle Autoren das Manuskript gelesen haben und mit der Veröffentlichung in der vorliegenden Form einverstanden sind. Es ist Sache des Autors, die Nach-druckerlaubnis für Abbildungen, Tabellen usw. aus anderen Publikationen zu beschaffen. Mit der Annahme des Manuskriptes zur Publikation gehen alle Rechte auf den Verlag über. Ohne schriftliche Genehmigung des Verlages dür-fen diese Publikationen oder Teile daraus nicht in andere Sprachen übersetzt oder in irgendeiner Form mit mechanischen oder elektronischen Mitteln (einschließlich Fotokopie, Tonaufnahme und Mikrokopie) reproduziert oder auf einem Datenträger oder einem Computersystem gespeichert werden. Geschützte Markennamen müssen mit einem hochgestellten ${ }^{\circledR}$ bezeichnet werden. Die Verantwortung für die korrekte Befolgung dieser Vorschrift liegt aus-schließlich beim Autor.

2. Manuskripte 
Diese sollen in 1 ' $1 / 8$-zeiligem Abstand geschrieben sein, links und rechts einen angemessen breiten Rand aufweisen und (einschließlich Titelseite und Litera-turverzeichnis) kontinuierlich durchnumeriert sein. Folgende Gliederung wird empfohlen:

Titelseite mit Titel und Kurztitel der Arbeit in Deutsch und Englisch; Autoren-angabe; Institutsangabe in der Landessprache der Autoren.

Zusammenfassung und Schlüsselwörter in Deutsch und Englisch. Zusammen-fassungen sollen 20 Schreibmaschinenzeilen nicht überschreiten und wie folgt gegliedert sein (n. Haynes RB et al. Ann Intern Med 1990; 113:69-76): Für klinische Studien in Ziel, Design, Rahmen, Patienten (Teilnehmer), Interventionen, Ergebnisse, Schlußfolgerungen, Schlüsselwörter. Für experimentelle Untersuchungen in Hintergrund, Material und Methodik, Ergebnisse, Schlußfolgerungen, Schlüsselwörter. Für Übersichtsartikel in Ziel, Quellen, Auswahlkriterien, Zusammenfassung, Schlußfolgerungen, Schlüsselwörter. In die Zusammenfassung gehören keine Literaturzitate, Tabellen, Abbildungen und Abbildungs-und Tabellenhinweise sowie allgemein gehaltene Aussagen. Zu einer Arbeit gehören 3-5 Schlüsselwörter.

Ethical and legal prerequisites: Manuscripts handed in for publication dealing with examinations of probands and patients must include the declaration that the trial protocol has been approved by an ethical committee and thus meets the standards of the Declaration of Helsinki (1964). At the same time the proband's informed consent has to be included in the manuscript. Information suitable to reveal the proband's identity is to be avoided.

Animal experiments demand consent as well and must meet the requirements of the German laws protecting animals in the version of 1986. A reference to this approval must be included in the manuscript. Articles from outside the FRG must include a comparable notice.

1. General Remarks - Publishing Laws

Please send your manuscript directly to the managing editor: Prof. Dr. Helmuth Forst, Klinikum Großhadern, Institut für Anästhesiologie, Marchioninistraße 15, W-8000 Munich 70 (FRG), Fax (089) 7409054. Contributions are classified as review articles, original papers, ongoing clinical studies, short communications, casuistic contributions, clinical pathological conference, congress reports, clinical information and letters to the editors. Original papers, ongoing clinical studies and short communications should be written in English. All other contributions may be handed in optionally in German or English.

The manuscript should be submitted in four copies ready for printing. In a covering letter all authors of a manuscript must confirm by their signature that the submitted paper, or parts of it (with the exception of communications for congresses), was not published previously nor that it is under simultaneous consideration for publication elsewhere. The authors are furthermore asked to confirm that all of them have read the manuscript and that they agree to have it published in its present form. Acceptance of a manuscript is based on the evaluation by several referees. Each author should always keep a copy of the manuscript. The publisher reserves the right to edit the manuscript and decide on the layout.

It is the author's responsibility to obtain permission to reproduce illustrations, tables etc. from other publishers. Once the manuscript is accepted for publication, all the rights will be retained by the publisher. The publication, or parts of it, may not be translated into other languages, or reproduced by any mechanical or electronic means (including photocopying, recording and microcopy-ing), or stored in a retrieval system without the publisher's written permission. Registered trade names must be marked with the superscript registration symbol ${ }^{\circledR}$. It is the sole responsibility of the author to ensure that this rule is followed properly.

2. Manuscripts 
The manuscripts should be typed in a spacing of IVa lines with adequately wide margins (left and right). They should be consecutively numbered (including front page and reference list). We recommend the following division:

Front page with title and short title in German and English; author's name, institute name in the native language of the authors.

Summary and Key Words in German and English. Summaries should not exceed 20 typewritten lines and be arranged in the following manner (according to Haynes RB et al. Ann Intern Med 1990; 113:69-76): Clinical studies in Objective, Design, Setting, Patients (Participants), Interventions, Results, Conclusions, Key Words. Experimental investigations in Background, Materials and Methods, Results, Conclusions, Key Words. Review articles in Objective, Data Sources, Selection Criteria, Summary, Conclusions, Key Words. Summaries should not include any references, tables, figures, references to figures and tables and general statements. Each article should have 3-5 key words.

Text pages should be divided into Introduction, Materials and Methods (optionally Patients and Methods), Results, Discussion. Footnotes (with numbers) are placed at the bottom of each page of the text.

Please use abbreviations as economically as possible. Special abbreviations should be written in full when first mentioned followed by the abbreviation in parentheses, e.g. adenosine monophosphate (AMP).

(C) 1992 S. Karger GmbH, Freiburg

Der Textteil der Arbeit soil gegliedert sein in Einleitung, Material und Metho-den (oder: Patienten und Methoden), Ergebnisse, Diskussion. Fußnoten (ge-gebenenfalls numeriert) am unteren Rand jeder Textseite. Abkürzungen bitte möglichst sparsam verwenden. Bei speziellen Abkürzungen jeweils beim ersten Auftreten das Wort ausschreiben und die später verwendete Abkürzung in Klammern folgen lassen: z.B. Adenosin-Monophosphat (AMP). Danksagungen sollten unmittelbar dem Text folgen und dem Literaturverzeich-nis vorangestellt sein. Das Literaturverzeichnis soil nur die im Text zitierten Publikationen enthalten. Die Literatur ist entsprechend der Reihenfolge im Text zu numerieren. Es sol-len nur Arbeiten, die entweder publiziert oder zur Publikation angenommen sind, zitiert werden. Der Passus «in Vorbereitung» oder «persönliche Mittei-lung» ist zu vermeiden.

Literaturzitate werden mit oder ohne Angabe des Erstautors in den Text einge-fügt, z.B. [1] oder Romberg [1] oder Romberg et al. [1].

Zur Abfassung von Literaturzitaten gelten folgende Beispiele:

Darstellungsschema einer Zeitschriftenreferenz:

Kauffman HF, van der Heide S, Beaumont F, Blok H, de Vries K: Class-specific antibody determination against Aspergillus fumigatus by means of the enzyme-linked immunosorbent assay. III. Comparative study: IgG, IgA, IgM ELISA titers, precipitating antibodies and IgE binding after fractionation of the antigen. Int Arch Allergy Appl Immunol 1986;80:300-306. Darstellungsschema einer Buchreferenz:

Hardy WD Jr, Essex M: FeLV-induced feline acquired immune deficiency syndrome: A model for human AIDS, in Klein E (ed): Acquired Immunodeficiency Syndrome. Prog Allergy. Basel, Karger, 1986, vol 37, pp 353-376.

Die Anzahl von Abbildungen und Tabellen soil niedrig gehalten werden und darauf abzielen, den Text zu erläutern. Abbildungen werden mit (Abb. 1), Tabellen mit (Tab. 1) in den Text eingefügt. Bereits im Text genannte Zahlen bedürfen keiner Wiederholung in einer Tabelle. Umgekehrt brauchen die in Tabellen zusammengestellten Zahlen nicht im Text wiederholt zu 
werden. Farbabbildungen können angenommen werden, bedürfen aber eines Repro-duktionsund Druckkostenzuschusses, den der Autor zu tragen hat. Abbildungsvorlagen sind 4 fach als Papierabzüge einzureichen. Vorlagen nicht aufkleben, lochen oder mit Büroklammern anheften; auf der Rückseite den Namen des Autors, den Titel des Beitrags, die Angabe, wo «oben» ist, sowie die Bildnummer angeben.

Alle Abbildungen und Tabellen sind mit einer Legende zu versehen. Alle Legenden einer Arbeit werden auf einer gesonderten Seite zusammengestellt. Die Legenden sind kurz und präzise zu halten und sollen die Abbildungen bzw. Tabellen vollständig erklären. Die Interpretation der Daten erfolgt nicht in der Legende, sondern ausschließlich im Text.

Autorenadresse

Bitte Postanschrift des Autors am Schluß der Arbeit vollständig angeben.

3. Umfang von Manuskripten

Originalarbeiten (Gliederung s.o.) sollen 10 Textseiten nicht überschreiten. Kurzmitteilungen folgen der Gliederung von Originalarbeiten und sollen 5 Textseiten, 5-10 Literaturhinweise und max. 1 Abbildung und 1 Tabelle (oder wahlweise 2 Abbildungen oder Tabellen) nicht überschreiten. Schwerpunkte von Kurzmitteilungen sollen neue Ergebnisse wissenschaftlicher Arbeiten, auch in Form sogenannter vorläufiger Mitteilungen, und auch neue Studienansätze experimentell oder klinisch - sein. Verlag und Schriftleitung wollen erreichen, daß solche Arbeiten innerhalb kürzester Zeit publiziert werden. Selbstverständlich bleibt es dem Autor überlassen, zu einem späteren Zeit-punkt eine ausführliche Fassung einzureichen.

Übersichtsarbeiten folgen nicht der Gliederung von Originalarbeiten. Titel-seite, Zusammenfassung und Literaturverzeichnis (s.o.) sind jedoch erforder-lich.

4. Kosten und Sonderdrucke

Übersteigen die Kosten der Autorkorrektur 10\% der Satzkosten, müssen diese

dem Autor in Rechnung gestellt werden.

Dem Autor stehen 40 Gratissonderdrucke seiner Arbeit zu.

Acknowledgments should be placed directly after the text, and before the list of references.

The list of references should include only the publications cited in the text. The references should be numbered according to their order of appearance in the text. It is recommended to quote only articles which have been either published already or accepted for publication.

Please avoid passages like 'in preparation' or 'personal communication'. Quotes from references are inserted into the text with or without the name of the first author, e.g. [1], or Romberg [1] or Romberg et al. [1].

For references the following examples are compulsory:

Outline of a magazine reference:

Kauffman HF, van der Heide S, Beaumont F, Blok H, de Vries K: Class-specific antibody determination against Aspergillus fumigatus by means of the enzyme-linked immunosorbent assay. III. Comparative study: IgG, IgA, IgM ELISA titers, precipitating antibodies and IgE binding after fractionation of the antigen. Int Arch Allergy Appl Immunol 1986;80:300-306. Outline of a book reference:

Hardy WD Jr, Essex M: FeLV-induced feline acquired immune deficiency syndrome: A model for human AIDS, in Klein E (ed): Acquired Immunodeficiency Syndrome. Prog Allergy. Basel, Karger, 1986, vol 37, pp 353-376.

The number of figures and tables should be limited and aim to illustrate the text. Figures are listed in the text as (fig. 1), tables as (table 1). Figures already mentioned in the text need not be repeated in a table. Accordingly, numbers used in tables need not be repeated in the text. Figures 
in color may be accepted, provided the author is prepared to defray the costs involved. Do not fasten original figures with glue or paper clips or punch holes in them. Please state on the back the author's name, the title of the article, the 'top' instruction and the number of the figure.

All figures and tables must include a legend. All legends should be listed together on a separate page. Legends should be kept short and precise and should illustrate the figures and tables exhaustively. The data should not be interpreted in the legend but exclusively in the text. Author's address

Please give the author's full address at the bottom of the article.

3. Volume of Manuscripts

Original papers (framework see above) should not exceed 10 text pages. Short communications adhere to the framework of original papers and should not exceed 5 text pages, 5-10 references and a maximum of 1 figure and 1 table (optionally either 2 figures or tables). Short communications should focus on the results of scientific studies, also in the form of so-called provisional reports as well as new scientific approaches either experimental or clinical. It is the publisher's and the editorial staff's aim to manage the publishing of such articles within the shortest period of time possible. It goes without saying that the author is at liberty to hand in a complete version at a later date. Review articles do not adhere to the framework of original papers. The title page, a summary and a list of references (see above) are, however, compulsory. 4. Costs of Reprints

The author will be charged for corrections to the galley proofs entailing expenses in excess of $10 \%$ of the original typesetting costs. The author is entitled to 40 free reprints of his or her article.

342

Hinweise für Autoren · Instructions to Authors 